\title{
Research on the Impact of Energy Prices on Macroeconomics
}

\author{
Haiwen Long ${ }^{1,2}$ \\ ${ }^{1}$ Oxbridge College, Kunming University of Science and Technology, Kunming, 650106 \\ ${ }^{2}$ School of Economics, Yunnan University, Kunming, 650091
}

KEYWORDS: Energy Price; Macroeconomics Development; Financial Status

\begin{abstract}
China, in terms of a growing economy, increasing energy consumption in developing countries, since the reform and opening up and the impact of rising energy prices fluctuations on China's macro economy has become increasingly prominent, thus explore energy price volatility transmission mechanism to assess the impact of energy price fluctuations on macroeconomic would have great practical significance. Through the establishment of pulse technology and the impact of energy price shocks of the response function to analyze the impact of technology and the impact of energy price shocks on the economy. In this theory, based on the use of Chinese economic data empirical analysis, examine the effects of China's economic fluctuation characteristics and the fact that energy prices to economic fluctuations. Finally, put forward policy recommendations for energy price-related issues.
\end{abstract}

\section{Introduction}

China's energy pricing is still in the stage of government pricing, coal prices have been market-oriented reforms, but because there is no electricity liberalization, market-oriented coal price reform was not complete, there is a two-track contract price and the market price. Refined oil pricing mechanism reform has also been three times, trying to linkage with the international price fluctuations, but because of domestic oil benchmark prices approval lag, this pricing mechanism is not science. Approval by the NDRC price, coal prices in the period, the state launched / 0 coal linkage mechanism, but practice shows that this temporary price mechanism can not fundamentally solve the contradiction between coal price regulation and price liberalization between. Under the current energy pricing mechanism, China's energy price levels do not reflect the market supply and demand information, cause excessive demand for energy, particularly in recent years, the development momentum of high energy-consuming enterprises fully reflects the unreasonable price mechanism in the allocation of resources low efficiency. Meanwhile, under the existing pricing mechanism, governments often subsidize the production side, rather than directly on the consumer side subsidizing much often the result of the game between the government and energy companies. Therefore meaning that energy price reform, the establishment of a transparent pricing mechanism based on market supply and demand situation on the market pricing of energy, while countries needed to subsidize the consumption side, the amount of subsidy can be determined through hearings and other ways. At the appropriate time, the state will gradually step by step removal of subsidies. This is to play the role of energy prices in the allocation of resources, but also give full consideration to the different levels of energy prices, the level of acceptance of digestion, the impact of energy pricing reform for economic growth and social stability to a minimum. 


\section{Situation of Chinese Macroeconomic and Energy Markets}

Since the reform and opening up, China's economy has developed dagger jump. Total GDP in 1978 was only 364.52 billion yuan in 2009, this figure had increased to 34.050687 trillion yuan, an increase of 82 times the per capita GDP in this period grew by 5.9 billion yuan, the national per capita disposable income grew by almost 40 times, the Engel coefficient of urban and rural areas has been declining, this series of data show that China's comprehensive national strength continued to improve, but our extensive economic growth pattern has not changed.

China's total energy reserves are very rich reserves of primary energy in the world's top three. As of 2008, China's total energy is about four trillion tons of standard coal, less than $4 \%$ of the world total. According to data released by global energy network, as of April 2008, China's total oil resources of about 107.3 billion tons of proven oil reserves of about 20.6 billion tons, $19.19 \%$ rate of proven resources, mainly in the eastern part of our country and Western Region. Proven recoverable reserves of about 70 billion tons accounts for $34 \%$ of proven reserves. Chinese natural gas reserves are relatively low, according to the relevant departments predicted that by the end of 2008, China's total natural gas is about 46 trillion cubic meters of proven rate was $6.52 \%$, China's reserve-production ratio can be about 55 years, World natural gas reserves and production level of about 58 years. Chinese coal resources storage status than oil and natural gas resources much better. By the end of 2006, reserves of coal resources is about 1.0345 trillion tons of proven coal reserves of about 114.5 billion tons, and the remaining proven recoverable reserves of about 13 per cent of the global total, in the third world. At the current production rate, China's coal resources can be maintained for approximately 150 years of mining. Producing areas of coal resources and consumption uncoordinated regional distribution of coal resources are mainly located in the north-west, south-east of less distributed, while the consumption areas are mainly concentrated in the southeast region, which determines my domestic, transportation and sales patterns are: West coal shipped East, West East marketing and production North coal south, north east producing pin. In addition, changes in coal quality and varieties of each region is relatively large, asymmetrical distribution of this situation to our country's transportation system has brought a lot of pressure.

\section{Theoretical Analysis of Prices on the Macroeconomic}

Energy demand is derived demand, energy and the demand for goods and services produced for each set corresponding to the cause. With the improvement of people's living standards, demand for products and services will increase, causing the growth of energy demand; of course, depends on how much of the increase in goods and services, whether it is a necessity. Obviously, in the short term, changes in energy prices, use intensity have equipment and possible impact on alternative energy, and indirectly affect the macro; the long term, energy prices have the expected value corresponding processing equipment depreciation and equipment update an important impact, thereby affecting the social average level of technology and energy intensity. As we all know, economic growth is not just a simple increase in GDP, accompanied by a selection of lifestyle adjustment and economic structure. Overall, energy prices affect the demand for energy is generated through the following three channels: First, high energy prices led to improve energy efficiency and reduce the amount of energy consumption; the second is the high price of consumer goods has changed the composition of the residents of the price system, resulting in changes in relative prices, and reduce the demand for energy products; Third, high prices will impact on the overall economy, caused by the recession, due to economic growth and reduce the energy demand arising. 
Energy resources are not renewable, and its supply of resources and progress of the exploration and exploitation of the relevant technology. In terms of quantity, the manufacturer can determine the time and amount of resources mined in accordance with the principle of profit maximization, the supply is limited. The whole process from the point of view of energy consumption, consumers will trade-off between current consumption and future consumption, and energy prices will be an important factor to weigh in. Energy prices will increase in the energy industry as a factor input costs rise, reducing the total social supply and ultimately affects the macroeconomic aggregates. The process can move through demand and supply curves represented: when the demand curve is fixed, if rising costs, decreased supply of factors of production, the supply curve will shift to the left, by the aggregate supply curve to move on Si S2, the equilibrium point moved by the upper E1 E2, balanced moved production from the Y1 Y2, in the case of excess capacity, companies can not lower the cost increases in energy prices brought passed on to consumers. In this case, the downstream enterprises can only be compressed by reducing the scale of production, resulting in the reduction of social goods and services supplied to reduce the total social supply in turn lead to rising consumer price level, the price level rose from Pl to P2, this situation is stagflation. Conversely, when the cost reduction, the supply curve will move to the right, then it will increase output, lower price levels.

In a market economy, energy Value depends on its usefulness and scarcity. In the process of development and utilization of energy is bound to establish ownership. Property is a modern market economy is an important concept, it is intuitive property from property rights. Property right is a prerequisite for trading, property ownership is the basis of economic operation, the transfer of property rights is the core of goods and services traded. Soil property rights have included: ownership, usufruct, use and disposal rights. Who owns the resource ownership is a problem; the right to use is whether the use of resources, and in what manner the rights to use resources; income right through the use of resources, and the right of access to benefits; the right of disposal is the right to dispose of resources. These property rights are defined by law. The question is an important resource value reflects the property. Suppose a resource does not exist in the area of property rights, any person who does not pay any cost conditions, the use of resources in various ways, this situation is not only in the number of resource limited circumstances, it will not be a shortage, and in this case, there is no resource value. In China, the countries are mining resources of the country, but the developers of resources are different corporate ownership. State mine developers to transfer the right to use resources, is bound to want to get financial compensation, which formed an absolute mine ore rent. Even if the mining resources are poor, the owner will be required to get the rent.

\section{Strategies to Address the Energy Price Shocks}

Energy is an important factor in the national economy can not be ignored and the price changes will undoubtedly affect the development of our national economy. China's current lack of energy reserves, energy consumption structure is irrational, the energy management system is also not perfect, we must establish a comprehensive energy strategy as soon as possible to cope with the energy price shocks. With the expansion of the energy supply and demand, energy security, increasing pressure, the emerging role of energy reserves, energy reserve in the following aspects: First, sufficient energy reserves to cope with fluctuations in market prices and supply of energy and other emergencies, to ensure security of energy supply; secondly when energy prices slump, purchasing more energy, be able to obtain economic benefits. Energy reserves should be divided into three levels with BU (see table below): First, reduce production costs, third is to ensure normal social and economic cloud, the second is the prevention of international energy crisis and ensure 
security of energy supply. Strategic energy reserves before some developed countries are very adequate, Japan, the United States, Germany and France, the amount of oil reserves can supply each countries 169 days, 158 days, 117 days and 96 days of consumption, while China's energy reserves can only sustain 21 days demand, in addition to the United States also reduce the country's oil production, increase energy imports, while Japan imported coal mine reclamation, these moves are making the connection of energy reserves. Our country started in 2003 when the oil reserve plan, prepare clever in the year, in three stages 90 days of imports-scale oil reserve facilities. Despite the strategic energy reserves, China started relatively late, the implementation process is relatively passive, but if continuous effort, the situation can still be greatly altered.

\section{Conclusion}

This paper analyzes the impact of technology and the impact of energy price shocks on the main economic variables. The results showed that the extent of the impact of technology is greater than the energy price shocks, but the impact of energy price shocks are more persistent, so the policy by slowing economic fluctuations during energy prices should be taken seriously. China is now in the mid-industrialization, consume a lot of energy for our country's dependence on the world's energy gradually deepened, it must be based on the combination of national policy, energy conservation, development of new energy sources, while strengthening friendship and cooperation with other countries.

\section{Reference:}

[1] Aubhik Khan and Julia K Tomas Inventories and Business Cycle:. An Equilibrium Analysis of (S, s) Policies [J]. The American Economic Review, 2007 (97): 76-88.

[2] Balke, N S., S P. A. Brown, and M. K. Yucel Oil Price Shocks and the U. S. Economy:... Where does the Asymmetry Originate [J]. The Energy Journal, 2002 (23): 27-52.

[3] Brown, S.P.A., and M. K. Yucel Energy Prices and Aggregate Economic Activity:. An Inter-pretative Survey [J]. The Quarterly Review of Economics and Finance.2002 (42):. 193-208.

[4] Finn, M G. Perfect Competition and the Effects of Energy Price Increases on Economy Activity [J]. Journal of Money Credit and Banking, 2000 (32): 4-16.

[5] George W. Stadler, "Real Business Cycles" Journal of Economics Literature December 1994,171-173. 